УДК 330(477)

\title{
РОЗВИТОК ЕКОНОМІКИ УКРАЇНИ НА ОСНОВІ ПРИНЦИПУ РІВНОПРАВНОСТІ ВІДНОСИН ДЕРЖАВИ, БІЗНЕСУ ТА СУСПІЛЬСТВА
}

\author{
Дикань В.Л., д.е.н., професор, \\ Толстова А.В., к.е.н., доцент (УкрДУЗТ)
}

\begin{abstract}
В статті проаналізовано основні тендениії розвитку України, визначено ключові причини невдалих трансформачійних прочесів національної економіки. Доведено необхідність переходу на модель розвитку економіки, яка базується на принципі рівноправності держави, бізнесу, суспільства. Формування економіки на основі такого принципу дозволить розвинути конкурентні відносини, досягти групового співробітництва держави, бізнесу та суспільства, щьо сприятиме забезпеченню добробуту країни. Економічний розвиток краӥни запропоновано здійснювати на основі симбіозу інституиіалізованих та неринкових методів задоволення потреб суспільства. Визначено основні напрямки розвитку економіки країни.
\end{abstract}

Ключові слова: держсав, бізнес, суспільство, держсавне регулювання, інноваційне середовище, індустріальний парк, інвестиційна політика.

\section{РАЗВИТИЕ ЭКОНОМИКИ УКРАИНЫ НА ОСНОВЕ ПРИНЦИПА РАВНОПРАВИЯ ОТНОШЕНИЙ ГОСУДАРСТВА, БИЗНЕСА И ОБЩЕСТВА}

\author{
Дикань В.Л., д.э.н., профессор, \\ Толстова А.В., к.э.н., доцент (УкрГУЖТ)
}

В статье проанализированы основные тенденции развития Украины, определеньл ключевые причины неудачных трансформачионных прочессов национальной экономики. Доказана необходимость перехода на модель развития экономики, основанной на принципе равноправия государства, бизнеса, общества. Формирование экономики на основе такого приниипа позволит развить конкурентные отношения, достичь группового сотрудничества государства, бизнеса и общества, что будет способствовать обеспечению благосостояния страньл. Экономическое развитие странь предложено осуществлять на основе симбиоза институциализированных и нерыночных методов удовлетворения потребностей общества. Определены основные направления развития экономики страны.

Ключевые слова: государство, бизнес, общество, государственное регулирование, инновационная среда, индустриальный парк, инвестиционная политика.

(C) Дикань В.Л.,

Толстова А.В.

Вісник економіки транспорту і промисловості № 63, 2018 


\title{
DEVELOPMENT OF THE ECONOMY OF UKRAINE BASED ON THE PRINCIPLE OF THE EQUALITY OF RELATIONS OF THE STATE, BUSINESS AND SOCIETY
}

\author{
Dykan V.L., doctor of sciences, professor, \\ Tolstova A.V., Ph.D., Associate Professor (USURT)
}

The article analyzes the main trends of Ukraine's development, identifies the key causes of the failed transformational processes of the national economy. It is determined that negative development tends to be caused by the imbalance and inefficiency of the existing system of public administration, the implementation of inconsistent reforms that are of a sectoral nature, inconsistency of structural priorities aimed at solving current problems, corrupting the distribution of capital, focusing political, economic and corporate power in "one hand" and lead to economic decline of the country, impoverishment of the population, growth of social tension.

The necessity of transition to the model of economic development, which is based on the principle of equality of state, business, society, is proved. The separation of the political interests of the state and the economic interests of the country, the achievement of economic justice in the relations between the state and the business community will enable the formation of an economic policy aimed at satisfying national interests, developing socially responsible business, and ensuring social security of the population. Effective management of the process of coordination of interests and coordination of the state, business, society as the main institutions of a market economy provides for taking into account new trends in development and achievement of certain strategic and tactical tasks of the country.

Economic development of the country is proposed on the basis of the symbiosis of institutionalized and non-market methods of meeting the needs of society. The basic directions of development of the country's economy are defined, which include: development of the industrial complex through the formation of industrial parks, clusters; development of agroindustrial complex; development of the IT sector; development of small and medium business; development of social entrepreneurship.

One of the main instruments of economic development of the country is the investment environment, which is formed under the influence of fiscal policy, regulation of the financial services market and interaction of the financial and real sectors of the economy.

Key words: state, business, society, state regulation, innovation environment, industrial park, investment policy.

Постановка проблеми. Динамічні зміни та трансформація світової економіки, інтеграція в глобальний ринок обумовлюють необхідність переходу на нові інноваційні стратегії розвитку країни, які передбачають впровадження ITтехнологій, використання цифрових інформаційних технологій в управлінні та функціонуванні суб'єктів господарювання й суспільства в цілому, що супроводжується залученням штучного інтелекту, роботизацією виробництва,

\begin{tabular}{l} 
розвитком пемослової біології, \\
переходом на безпілотний транспорт, \\
переходом на електронні гроші, \\
споживання послуг або товарів, які \\
надають онлайн-торгівля та електронне \\
управління і т.д. Такі трансформації \\
економіки мають багатовимірний характер, \\
призводять до змін у сферах суспільного \\
життя, потребують створення нових форм \\
та способів організації взаємодії між \\
державою, бізнесом, суспільством. \\
Ефективне \\
\multicolumn{4}{c}{ управління процесом }
\end{tabular}

розвитком промислової біології, переходом на безпілотний транспорт, переходом на електронні гроші, споживання послуг або товарів, які надають онлайн-торгівля та електронне управління і т.д. Такі трансформації економіки мають багатовимірний характер, призводять до змін у сферах суспільного життя, потребують створення нових форм та способів організації взаємодії між Ефективне управління процесом 
узгодження інтересів та координація держави, бізнесу, суспільства як основних інститутів ринкової економіки забезпечує врахування нових тенденцій розвитку та досягнення визначених стратегічних та тактичних завдань країни.

Однак за часи незалежності в Україні відбулося об'єднання політичної та економічної влади, держава лобіює власні інтереси політичної еліти, ігнорує інтереси суспільства та думку бізнесу щодо вибору стратегії розвитку країни. Це призводить до конфліктності відносин держави, бізнесу та суспільства, спроб бізнесу увійти в політику 3 метою впливу на можливості та ресурси, прагнення громадських організацій вплинути на владу шляхом обурення та протестів.

В таких умовах основою успішного економічного розвитку України $\epsilon$ формування моделі розвитку економіки на основі встановлення рівноправності держави, бізнесу та суспільства, оскільки саме відокремлення політичних інтересів влади та економічних інтересів країни, досягнення економічної справедливості у взаємовідносинах держава-бізнессуспільство дозволять сформувати економічну політику, направлену на задоволення національних інтересів, розвиток соціально-відповідального бізнесу, забезпечити соціальну захищеність населення.

Аналіз останніх досліджень та виділення невирішеної частини загальної проблеми. Проблеми розвитку економіки України неодноразово обговорювалися вченими, політиками та економістами, які визначали ключові причини існуючих векторів розвитку, пропонували різні шляхи, моделі відродження економічної потужності країни.

Більшістю із них шляхи подолання складаної соціально-економічної ситуації вбачають у впровадженні інноваційної моделі розвитку, перехід на цифрову економіку, стимулювання інвестиційної активності та посилення державної підтримки промисловості. Вагомий внесок у вирішення проблем розвитку економіки України та забезпечення економічної стабілізації внесли такі вітчизняні вченінауковці, як: Бубенко П.Т., Геєць В.М., Дикань В.Л., Збаразська Л.О., Кіндзерський Ю.В., Липов В.В., Проскуринова В.Е., Шульга О.А. та інші [1-12]. Разом із значною кількістю пропозицій i розробок виникає необхідність перегляду основних принципів формування економічної системи країни, взаємодії держави, бізнесу та суспільства, що насамперед визначає модель подальшого розвитку економіки України.

Метою статті $є$ визначення моделі розвитку економіки країни на основі принципу рівноправності держави, бізнесу та суспільства.

Виклад основного матеріалу. 3 урахуванням глобальних процесів трансформації за 27 років структура української економіки значно деградувала на фоні тих процесів, які відбувалися в країнах-лідерах, формуючих ядро капіталістичного центру [11]. В той час як світова економіка зросла більш ніж удвічі, українська й досі на третину нижче рівня 1991 року. В результаті неефективної економічної політики структура економіки України деградувала та за своїми характеристиками наблизила іiі до менш розвинених країн, що супроводжується зниженням потенціалу економічного зростання.

За критеріями Індексу глобальної конкурентоспроможності, розрахованого на основі даних Всесвітнього економічного форуму (2016-2017pp.) економіка України знаходиться на стадії переходу від етапу розвитку 3 домінуванням факторів виробництва до стадії розвитку, де домінують фактори ефективності з 5-10\% часткою інновацій. Сьогодні економіка України характеризується спеціалізацією на експорті сировини та продукції іiі первинної обробки, низьким рівнем ВВП на душу населення, який на 2018 рік 
складає 2,82 тис.долл (що майже в двічі нижче рівня ВВП країн, що розвиваються), зростанням державного боргу на 10,98\% (3 яких на зовнішні борги приходиться 47,2 млрд доларів, що в 2,6 рази більше поточного рівня валютних запасів країни), тінізацією економіки ( яка сягає $33 \%$ ВВП), зростанням рівня безробіття, підвищенням ціни на газ та комунальні послуги, зниженням спроможності населення [13-15].

Основними причинами невдалих трансформаційних процесів національної економіки $\epsilon[2,5,16]$ : - поспішна

лібералізація економіки, котра вимагала після адміністративно-планової економіки 3 жорсткою системою державного управління, виробництва за держзамовленням, звільнити економіку країни від надмірного управління 3 боку державної влади на ринкові механізми. Це обумовило перерозподіл державної власності, розвиток корупції i, як наслідок, помилково обраний курс економічного розвитку, впровадження недоцільних та непослідовних реформ, зруйновані великі виробничо-технологічні розділені підприємства, ліквідовані колективні підприємства сільського господарства, які складали ядро економічного потенціалу країни;

\section{- незбалансованість}

неефективність існуючої

та

державного управління, яка на сучасному етапі не спроможна виробляти послідовну та дієву стратегію економічного розвитку України шляхом реалізації реформ, які направлені на втілення інтересів суспільства, а не на власні пріоритети влади;

- впровадженням непослідовних реформ, які мають галузевий характер, неузгодженістю структурних пріоритетів, спрямованих на вирішення поточних проблем призвели до посилення структурних диспропорцій економіки, прискорення низькотехнологічного використання виробництва, промисловості старих
домінування технологій 3 випуском продукції низької стадії переробки, велика частка сировинної продукції в експорті, низький рівень високотехнологічного виробництва та деіндустріалізація країни;

\section{- корумпований}

розподіл

капіталу, на основі приватизації державної власності, що в результаті призвело до формування в країні олігархії, створення олігархічних кланів, в яких зосереджено державні ресурси та багатства;

- політична нестабільність країни.

Відсутність чітко встановленої системи цінності, ідеології держави, єдиної стратегії економічного розвитку, ефективної системи державного управління, все більше посилюють політичне протистояння, боротьбу за владу i можливість контролювати у своїх руках ресурси, породжують соціальну напруженість, гальмують розвиток суспільства, закладають основи економічної кризи;

- наявність нерозривного зв'язку між політичними та економічними траєкторіями розвитку, що призвело становлення олігархії, яка слугує виключно вузькому колу економічної еліти.

Для трансформаційного періоду характерно використання політичної влади 3 метою отримання економічної влади. Це призвело до формування олігархії, захисту корисних інтересів правлячого класу, соціальної нерівності, несправедливого та нераціонального співвідношення благ між окремим групами населення, корупції, відсутності контролю та інших негативних змінах економіки та суспільства. Проблеми відносин, які в цей період склалася між бізнесом та державою, економічною та політичною владою доцільно вирішувати на основі розробки та реалізації соціальної теорії, відповідно до якої економічна, політична, воєнна, технологічна, освітня та культурна влади $\epsilon$ взаємопов'язані та взаємозамінні, а відповідно повинні бути i рівноправними [4]. Рівноправність 
держави, бізнесу та суспільства повинна полягати в узгодженні економічних інтересів країни, можливості впливу на формування та реалізацію стратегічних напрямків розвитку економіки України в рівній ступені, справедливому розподілі відповідальності за їх результати. Такі відносини держави, бізнесу, суспільства передбачають взаємо відповідальність кожного учасника відносин за виконання свої зобов'язань. Впровадження принципу рівноправності держави, бізнесу та суспільства дозволить розвинути конкурентні відносини, досягти їх міжсекторального співробітництва, метою якого $€$ забезпечення добробуту країни.

Оскільки формування ринкових відносин за своїми результатами може мати руйнівний характер та не має морального фундаменту, перед державою постає завдання гармонізації діяльності державних інститутів, релігійних організацій $з$ метою підтримки та розвитку таких якостей українського суспільства, як взаєморозуміння, відкритість. взаємодопомога, трансформаціі держави свідчить, що реаль сила держави свідчить, що реальна сила держави, як найбільш розвиненого суспільного інституту, залежить від того настільки вона відображає суспільні ідеї, пріоритети, ціннісно-нормативні установки.

Під час впровадження українських реформ держава віддалилась від суспільних процесів, що призвело до втрати основних захисних та системоуторюючих функцій служіння суспільству. Оскільки держава є ініціатором економічних реформ, зміни суспільно-економічного устрою, тому вона несе відповідальність за результати своєї діяльності [2]. Сьогодні наслідками такої діяльності $є$ прояв низького рівня довіри суспільства державним інститутам. Слід зазначити, що без тісного співробітництва держави 3 суспільними організаціями шляхом формування соціальних інститутів, розбудови соціальної інфраструктури, підтримки розвитку соціального підприємництва не можливо досягти успішного реформування економіки та впровадження активної економічної політики.

Одним із ключових факторів, які негативно впливають на розвиток економіки країни є тиск глобалізаційного світу. Оскільки транснаціоналізований капітал $є$ макрорегульованим, його вплив сильніший за національні держави, які залежать від зовнішнього впливу кредиторів [2]. Зазвичай надання позик, грантів, розвиток відносин та забезпечення різних додаткових прав пов'язанано 3 виконанням додаткових вимог. Свідчать про такий вплив і відносини між Україною та МВФ. Так, головним умовами МВФ щодо надання траншу $€$ зменшення навантаження на державний бюджет шляхом скорочення соціальних виплат, ліквідація різниці ціни на газ між споживачами та корупційною складовою при іiі нарахуванні, тобто привести до імпортного паритету. Однак скорочення соціального сектору призводить до зростання соціальної нерівності, зубожіння населення та зростання соціального напруження, що суперечить національним інтересам країни. Подолання такого впливу слід здійснювати шляхом встановлення рівноправ'я взаємодії ринкової сили бізнесу і держави, яке визначає діяльність інститутів, формуючи ринкові сили та спирається на соціальні норми, встановлені суспільством.

Розвиток економіки базуючись на принципі рівноправності держави, бізнесу та суспільства повинен здійснюватися на основі симбіозу інституціолізованого шляху (відповідно до законів ринку) та неринкових методів 3 надання населенню колективних благ на основі пільгового або безкоштовного задоволення державою індивідуальних або колективних потреб. Сучасні перетворення в економіці країни супроводжуються розширенням сфери впливу ринкових відносин, в тому числі, i на соціально значимі сфери: освіту та охорону здоров'я. Невраховані наслідки 
змін в даних сферах можуть призвести до поглиблення нерівенства. Вирішення зазначеної проблеми можливо за рахунок посилення взаємодії бізнесу та держави, які забезпечать економічне зростання шляхом реалізації ринкової діяльності, що сприятиме підвищенню рівня добробуту населення.

Як зазначалося в умовах рівноправності держави, бізнесу та суспільства зростає роль інститутів, які діють поза ринкових принципах. Інститути повинені враховувати спадкоємність традицій, ідей, духовного світу населення, системи ціннісних уявлень та будуватися на взаємодії окремих елементів, що визначають цілісність економічної та суспільної системи в цілому, мають державну підтримку. Вони забезпечують, 3 одного боку, суспільну діяльність, з іншого - господарську. Формування інституційного середовища дозволить вирішити проблему домінування впливу політичного циклу над економічною політикою.

Стратегічно-важливими елементами інституційного середовища $\epsilon$ інститути розвитку, інвестиційні та соціальні інститути. Основне завдання інститутів розвитку полягає в забезпеченні та підтримці інноваційного розвитку всіх сфер економіки України шляхом формування інноваційно-технологічного середовища. Інвестиційне забезпечення розвитку економіки країни шляхом формування державних та недержавних інвестиційних фондів, що визначають інвестиційне середовище $\epsilon$ ключовим завданням інвестиційних інститутів. Діяльність соціальних інститутів слід направляти на забезпечення соціального розвитку країни, соціальної захищеності населення, морально-культурному розвитку суспільства, зростанню його добробуту.

Така інституціональна система взаємодії держави, бізнесу, суспільства сприятиме формуванню загальних правил поведінки суб'єктів господарювання, створення державних та недержавних інститутів, які забезпечать ринкове (на конкурентних основах) функціонування галузей та суб'єктів, задіяних в процес ринкової взаємодії. Це дозволить вирішити проблему ефективного власника, що захистить суспільство від його ефективної діяльності.

Ключова роль в економічних перетвореннях належить системі пріоритетів, які повинні відповідати національним інтересам країни. Економічна політика країни повинна сприяти розвитку бізнесу на принципах конкуренції та соціальної відповідальності.

Основними умовами економічних перетворень в Україні $\epsilon$ політична і економічна стабільність в державі; довіра до влади і бізнесу з боку міжнародного співтовариства; комплексне планування i реалізація проекту за участю держави та бізнесу, науки та представників IT, різних галузей економіки; поетапна його реалізація 3 урахуванням експериментальної стадії; наявність державних програм і злагодженої системи управління під контролем держави 3 урахуванням інтересів усіх сторін і досягнення соціальної, економічної, екологічної ефективності; наявність відповідної науково-технічної бази; можливість здійснення великих інвестицій в нові техніку i технологію, розвиток цифрової інфраструктури, в науку і освіту; зміни в системах управління і підготовки кадрів [17].

\section{Першочерговим}

завданням

розвитку слід визначити реформування системи державного управління, перегляд економічної політики, які повинні базуватися на принципах законності, моралі і права. Апарат управління, який безпосередньо виконує функції державного управління, зобов'язаний чітко дотримуватися чинного законодавства, керуватися такими чеснотами, як розсудливість, справедливість, помірність, пріоритетність інтересів суспільства, соціальна відповідальність та не 
порушувати прав суспільства, в тому числі, наданих Конституцією України. Для зняття соціальної напруженості в країні, в першу чергу, слід вести прозору економічну політику, з роз'ясненням всіх напрямів розвитку, заходів, які необхідно реалізовувати. Основними пріоритетами системи державного управління повинно бути забезпечення національних інтересів країни, регулювання цінової політики, удосконалення фіскальної політики, реприватизація стратегічно важливих для країни підприємств, забезпечення безпеки країни.

Стратегічними напрямами розвитку економіки пропонуємо визначити:

- розвиток промислового

комплексу шляхом формування індустріальних парків, кластерів;

- розвиток агропромислового комплексу;

- розвиток сектору IT-технологій;

- розвиток малого та середнього

бізнесу;

- розвиток соціального

підприємництва.

Розвиток промислового комплексу країни пропонуємо здійснювати шляхом формування індустріальних парків, кластерів, які $€$ міжгалузевими інтегрованими структурами, спрямованими на консолідацію науково-виробничих, інфраструктурних, промислових підприємств різних галузей, що дозволить створити інноваційно-технологічне середовище для формування декількох технологічно завершених ланцюгів 3 виробництва різнопланової високотехнологічної продукції.

В першу чергу об'єднання підлягають підприємства, об'єднані єдиним технологічним ланцюгом. До складу індустріальних парків повинні увійти промислові підприємства (зокрема, підприємства металургійного, енергетичного, машинобудівного, хімічного, вугільного, нафто-газового комплексів, підприємств транспортного машинобудування, приладобудування, виробництва

металорізальних

інструментів, металоконструкцій, ремонтні підприємства, підприємства по розробці IT, нанотехнологій) i підприємства, які концентрують у собі інноваційний, інтелектуальний i iнформаційний потенціали, як регіонів, так i країни в цілому. Об'єднання таких підприємств в єдину логістичну систему дозволить раціоналізувати систему управління матеріально-технічними потоками, мінімізувати витрати, підвищити інвестиційну привабливість підприємства, що, в свою чергу, буде сприяти модернізації виробництва, створення якісної високотехнологічної продукції, яка буде конкурентоспроможною на міжнародному ринку $[5,6,16]$.

Одним із важливих кроків в розбудові промислового комплексу України $є$ розвиток торгівельноекономічного співробітництва між Китаєм та Україною [18]. Створення китайськоукраїнського індустріального парку відкриє можливості промислового співробітництва в таких сферах, як виробництво устаткування для залізничного транспорту, енергетичного обладнання, машинобудування, в металургії, будівництві інфраструктури, комунікацій, атомної енергетики та енергозберігаючих технологій. Розширення взаємодії у використанні інноваційних технологій і виробничого ланцюга Китай i Україна матимуть змогу створення нових моделей промислового співробітництва, виробництва продукції з високою доданою вартістю, сприяючи процесу реіндустріалізації країни.

Крім того, створення китайськоукраїнського індустріального парку сприятиме залученню додаткових транзитних потоків через транспортні коридори країни, оскільки значна частина товарів з Китаю експортується до Свропи. Це, в свою чергу, сприятиме модернізації транспортних коридорів, залізничного транспорту, впровадження високошвидкісного руху. 
Розвиток

міжнародного співробітництва, створення індустріальних парків сприятиме реіндустріалізації промисловості, зростанню конкурентоспроможності підприємств за рахунок реалізації потенціалу ефективної взаємодії учасників парку, пов'язаного з їх географічно близьким розташуванням, включаючи розширення доступу до інновацій, технологій, «ноу-хау», спеціалізованих послуг i висококваліфікованих кадрів, а також зниженням трансакційних витрат, що забезпечує формування передумов для реалізації спільних коопераційних проектів i продуктивної конкуренції. Соціальний ефект такого об'єднання полягає в формуванні додаткових робочих місць, що сприятиме скороченню трудової міграції, зростанню рівня добробуту населення.

Розвиток агропромислового комплексу пропонуємо здійснювати по таким напрямкам:

відносин;

- трансформація

земельних

- формування інституційних та макроекономічних умов, що забезпечить підвищенню рівня аграрної культури, фінансової платоспроможності фермерів;

- розвиток сільськогосподарської кооперації, конкурентних відносин між суб'єктами господарювання;

- кластерна

організація

агропромислового виробництва;

- удосконалення механізмів

надання державної підтримки суб'єктам господарювання.

В умовах формування глобальної цифрової економіки важливою галуззю, за рахунок якої передбачається зростання ВВП та, яка сприятиме модернізації реального сектору економіки $є$ галузь ITтехнологій. Розвиток сфери IT-технологій потребує фінансової підтримки держави, оскільки продукція даної галузі конкурентоспроможна на міжнародному ринку. Основним напрямом розвитку даної сфери повинно бути не лише розробка нових технологій для міжнародного ринку, a i для забезпечення національних підприємств передовими технологіями, які дозволять прискорити процес модернізації промисловості та забезпечать перехід на новий технологічний рівень.

Важливе місце в розвитку економіки країни посідає розвиток малого та середнього підприємництва. Головним завданням держави $€$ забезпечення належних умов функціонування, доступність фінансових ресурсів. Розвиток підприємництва повинен здійснюватися на основі комплексного підходу, який передбачає забезпечення конкурентоспроможності підприємств за рахунок управління знаннями, розвитку інноваційної діяльності, кадрового, науково-технічного потенціалу, інтелектуалізації [18].

Новим напрямом розвитку економіки країни, який спрятиме реалізації принципу рівноправності держави, бізнесу та суспільства є соціальне підприємництво. Воно допомагає виконувати такі функції: надавати державні послуги в новий спосіб і задовольняти потреби громади; створювати робочі місця; збагачувати професійний досвід людей; розвивати громади, залучаючи до громадського життя маргіналізовані групи; знижувати соціальну напругу; розширювати активність громадян, які можуть самостійно розв'язувати свої проблеми та брати відповідальність за своє життя; відроджувати сільські й міські території та поліпшувати їхню соціальну інфраструктуру; підтримувати громадські ініціативи, інноваційні проекти й творчу активність тощо.

Ключовим інструментом розвитку соціального підприємництва $є$ підтримка держави, яка повинна супроводжуватися програмами розвитку соціальних підприємств, впровадженнями системи пільгового кредитування, вироблення національної стратегії розвитку соціального підприємництва, яка дозволила б скоординувати зусилля всіх зацікавлених сторін - підприємців, громадських 
організацій, донорських структур та держави. Потрібна чітка і скоординована робота тих, хто в цей процес вже залучений, а також фінансування окремих проектів, які дозволять вирішувати проблему системно.

Одним із основних інструментів економічного розвитку країни $\epsilon$ інвестиційне середовище, яке формується під впливом фіскальної політики, регулювання ринку фінансових послуг та взаємодії фінансового та реального секторів економіки.

Для забезпечення розвитку економіки ключовим завданням держави $\epsilon$ формування інвестиційної політики, яка спрямована на створення привабливого інвестиційного середовища та суттєвого нарощування обсягів інвестицій, розвиток інноваційної діяльності.

Основними завданнями державної інвестиційної політики повинні стати [19]:

- орієнтація на інноваційний шлях розвитку економіки України;

- визначення державних пріоритетів інвестиційного розвитку України;

- удосконалення нормативноправової бази у сфері інноваційної діяльності;

- створення строгої системи контролю інвестиційної діяльності;

- створення умов для збереження, розвитку й використання вітчизняного науково-технічного та інноваційного потенціалу;

- забезпечення взаємодії науки, освіти, виробництва, фінансово-кредитної сфери у розвитку інноваційної діяльності;

- ефективне використання ринкових механізмів для сприяння інноваційної діяльності, підтримка підприємництва у науково-виробничій сфері;

- розвиток міжнародної науковотехнологічної кооперації, трансферу технологій, захисту вітчизняної продукції на внутрішньому ринку та іiї просування на зовнішній ринок;
- фінансова підтримка, сприятлива кредитна, податкова i митна політика у сфері інноваційної діяльності;

- сприяння розвитку інвестиційної інфраструктури;

- інформаційне забезпечення

суб'єктів інноваційної діяльності;

- підготовка кваліфікованих кадрів у сфері інноваційної діяльності;

- створення рівних умов для суб'єктів господарювання різних форми власності;

- здійснення процесу інвестування на прозорих та цивілізованих засадах;

інвестиційних джерел.

$$
\text { поліпшення структури }
$$

Удосконалення інвестиційної

політики України слід починати 3 впровадження державного регулювання валютного курсу, удосконалення нормативно-правової бази у сфері інноваційної діяльності, впровадження строгої системи контролю інвестиційної діяльності, дослідження та розбірливості в потенційних інвесторів, впровадження ефективної пільгової політики, системи сповіщення влади про залучення інвесторів, формування бюджетних i не бюджетних інвестиційних фондів, залучення коштів великих підприємств в розвиток економіки країни.

Першочерговим заходом забезпечення економіки країни інвестиційними ресурсами є впровадження державного регулювання валютного курсу, яке пропонуємо здійснювати на основі обмеження руху в країні іноземної валюти, скорочення приватних фінансових організацій, які здійснюють обмінні операції, проведення операцій 3 обміну лише в Національному банку України або державних банках країни. Це дозволить зміцнити національну валюту, утримати кошти в країні, збільшити надходження до держбюджету країни.

3 метою забезпечення стабільності сприяння інвестування в довгострокові проекти розвитку економіки країни, відповідно до пріоритетних напрямків іiі 
розвитку, захисту їх від мінливих політичних умов слід впроваджувати практику формування багаторічного бюджету. Тривалість реалізації проектів індустріалізації, модернізації економіки може досягати 5-10 років. Ефективність реалізації зазначених проектів залежить від забезпеченості фінансовими ресурсами. Оскільки, країна розвивається в нестабільних політичних та економічних умовах, бюджет слід складати на найближчі 3-5 років, 3 урахуванням основних проектів модернізації економіки.

Іншою сферою участі держави як суб'єкта та джерела фінансових коштів $є$ розвиток різних форм приватнодержавного партнерства при збереженні державою контролю над стратегічними інфраструктурними мережами, підприємствами країни. Ефективним $\epsilon$ проведення спільного фінансування та партнерства. Органи управління, які об'єднують широкий спектр інтересів, також повинні покрити від 15 до 50 відсотків витрат, пов'язаних з конкретними проектами, за рахунок місцевих (державних або приватних) джерел.

Важливим

елементом

інвестиційного забезпечення розвитку економіки країни $\epsilon$ залучення крупного бізнесу на основі створення позабюджетних інвестиційних фондів підтримки розвитку країни.

Висновки. Підсумовуючи, слід зазначити, що 27 річний досвід реформування та розвитку економіки України свідчить про необхідність переосмислення основних принципів взаємовідносин між державою, бізнесом, суспільством та основ формування економічної системи країни. В сучасних умовах, формування глобальної цифрової економіки, відкритості національної економіки до зовнішнього впливу доцільним є формування моделі розвитку економіки, ключовим базисом якої $\epsilon$ принцип рівноправності держави, бізнесу та суспільства. Участь бізнесу та суспільства в узгоджені національних інтересів, формуванні та реалізації стратегій розвитку економіки України дозволить державі зміцнити свої позиції як гаранта реалізації стратегій економічного та соціального розвитку, визначених відповідно до національних інтересів, заручитися підтримкою суспільства щодо обраних курсів розвитку, сформувати сприятливі умови для розвитку бізнесу. Ключовим напрямками розвитку економіки на основі рівноправності держави, бізнесу, суспільства визначено удосконалення системи державного регулювання, забезпечення індустріалізації, модернізації промисловості, розвиток агропромислового комплексу, інноваційного розвитку малого та середнього підприємництва, формування інноваційного та інвестиційного середовища розвитку, розвитку соціального підприємництва. Забезпечення програм розвитку економіки слід здійснювати на основі формування потужної інвестиційної інфраструктури, інститутів, які акумулюватимуть фінансові кошти та на проектній основі перерозподілятимуть їх на інноваційні проекти розвитку економіки.

\section{ПЕРЕЛІК ВИКОРИСТАНИХ ДЖЕРЕЛ}

1. Бубенко П.Т. Інституційна динаміка просторової організації економічного розвитку: монографія.

П.Т. Бубенко. - Харків: ХНАМГ, 2008. $295 \mathrm{c}$.

2. Геейц B.M. Эндогенизация развития экономики в измерении равноправия отношений государства, бизнеса и субъектов голосования / В.М. Геейц // Экономика Украины. - 2018. - №7. - C.3-19

3. Геєць В.М. Довіра і розвиток в українських реаліях / Творення простору суспільної довіри в Україні XXI сторіччя: матер.міжнар.наук.-практ.конф. $\quad-\quad$ К.: ДВНЗ «Університет банківської справи», 2017. - С.15-30

4. Джейкобс Г. Политическая экономия неолиберализма и 
неолиберальная демократия // Мир перемен. - 2018. - №1. - С.8-21

5. Дикань В.Л. Концепція інноваційного розвитку економіки України / В.Л. Дикань // Вісник економіки транспорту і промисловості. - 2015. №52. - C.9-20

6. Дикань В.Л. Механизм восстановления машиностроительного комплекса Украины в условиях логистической интеграции / В.Л. Дикань // Вісник економіки транспорту i промисловості. - 2014. - №47. - С.9-14

7. Збаразська Л.О. Неоіндустріалізація в Україні: концепт національної моделі / Л.О. Збаразська // Економіка промисловості. - 2016. - №3 (75). - С. 5-32

8. Кіндзерський Ю.В. Промисловість України: стратегія і політика структурно-технологічної модернізації [Текст] / Ю.В. Кіндзерський. - Київ: НАН України, Ін-т екон. та прогнозування, 2013. - 536 c.

9. Липов В.В. Конкурентная стратегия развития Украины в условиях глобализации / В.В. Липов// Экономика Украины. - 2018. - №3. - С.21-33

10. Проскуринова В.Е. Стратегические приоритеты развития промышленных кластерных территориально-отраслевых объединений / В.Е. Проскуркина // Економічний простір. - 2012. - №64. - С.96-109

11. Сіденко В.Р. Глобальні структурні та тренди економіки України // Економіка та прогнозування. - 2018. - №1. - C. 37-57

12. Шульга О.А. Стратегические направления аграрной политики в Украине / О.А. Шульга // Экономика Украины. - 2018. - №5. - С.3-22
13. Украине предрекли $50 \%$ роста ВВП на душу населения [Электронный pecypc]. - Режим доступа: https://korrespondent.net/business/economics /4013226-ukrayne-predrekly-50-rosta-vvpna-dushu-naselenyi

14. Держборг України: скільки i кому винен кожен українець населения [Електроний ресурс]. - Режим доступу: https://www.epravda.com.ua/news/2018/08/2 0/639768/

$\begin{array}{cc}\text { 15. Украинская } & \text { экономика } \\ \text { выходит "тз "тени" } & \text { населения }\end{array}$
[Электронный ресурс]. - Режим доступа: https://www.segodnya.ua/economics/business / ukrainskaya-ekonomika-vyhodit-iz-teni1165012.html

16. Tolstova A.V. Cluster economy-a modern paradigm of economic development of Ukraine/ A.V. Tolstova // GISAP: Economics, Jurisprudence and Management. - 2016. - №11. - p. 6-11

17. Компаниец В.В. Концептуальный анализ перспектив цифровизации экономики и железнодорожного транспорта / В.В. Компаниец // Вісник економіки транспорту і промисловості. 2018. - №62Додаток. - С.197-200

18. Чжан Дун'ян Тенденції розвитку i перспективи торгівельноекономічного співробітництва між Китаєм та Україною / Чжан Дун'ян // Економіка України. - 2018. - №6. - С.3-12

19. Толстова А.В. Стратегічний розвиток економіки України: інвестиційний аспект: колективна монографія · Інноваційно-інвестиційні засади стійкого розвитку базових галузей національного господарства: колективна монографія / за ред..В.П. Ільчука. Чернігів: Чернігів.нац.ун-т, 2016. -С.329341

DOI 10.18664/338.47:338.45.v\%vi\%i.146213 